\title{
Design, Modelling and Experimental Investigation of an Economic Domestic STHW System Using T*SoI® Simulation in Botswana
}

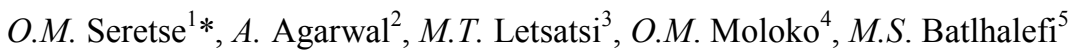 \\ ${ }^{1-5}$ Department of Mechanical Engineering, University of Botswana, Gaborone. Botswana \\ ${ }^{3}$ Department of Industrial design and technology, University of Botswana, Gaborone. Botswana
}

Abstract- The study describes a research and development directed at examining research and design a SHWS, and test a flat-plate solar collector capable of collection efficiency in excess of 50 percent at an inlet fluid temperature $22^{\circ} \mathrm{C}$. The model was analyzed using theoretical and mathematical analysis and the T*SOL ${ }^{*}$ simulation programme for solar thermal heating systems using radiation data to site. The average efficiency of mathematically designed system was higher as $70 \%$ than the designed value efficiency of 20 . The effectiveness of the collector was seen to be higher toward the start of the test and reductions consistently as the test advances with time. The economic analysis of the whole system desired was done with an initial total investment of US\$991.10. The economic performance of the system gives a positive net present value of US\$4662.13with a payback period of 0.7 years. At a steady radiation, the higher the heat absorbed, the higher the efficiency of the collector. The use of the flat plate solar collector for domestic and commercial heating (for eight person bread and breakfast) purposes in Gaborone is feasible since reasonable temperatures (outlet from the collector, $t_{\mathrm{o}}$ ) were realized.

Keywords- Solar energy, solar radiation, modelling, $\mathrm{T}^{*} \mathrm{SOL}{ }^{\circledR}$ simulation, solar collector

\section{Introduction-}

Energy plays the most essential role in the economic growth, progress, and development, as well as security and poverty eradication of any nation. Future economic growth crucially depends on the long-term availability of energy from sources that are affordable, accessible, and environmentally friendly. Due to the fast increase in the world population, the need for the energy increases rapidly. Most of the total consumed primary energy comes from the burning of fossil fuels as is the case of Botswana. The combustion of fossil fuels for energy has caused a significant increase in greenhouse gas emissions to the atmosphere, which is widely believed to be the primary cause of global warming. This has resulted in changes in sea levels, ecosystems and weather events, which have directly, affect people's health and way of life, as well as cause irreversible losses to plant and animal species [1].With that been the case, the use of renewable energy sources will be a good way to cope with energy and environmental problems. Renewable energy sources can easily replace fossil-fuels in the near future especially in stationary plants. Depleting reserves of fossil-fuels and environmental problems make it necessary to use the reserves more carefully [2]. Solar energy has great potential in space heating for buildings, water heating etc. owing to its low-grade energy characteristics and is the most important alternative to fossil fuels. Solar systems with feasible design and installation have very short payback periods and meet the energy demand very effectively.Solar water heating is an environmentally-friendly solar thermal system. An active solar heating system consists of solar collectors, a storage tank, a fluid circulation system between collector and tank, an auxiliary heating system, and a control system to regulate the overall operation [3]. Most solar collectors for buildings are either flat-plate or concentrating types. Both installations requires long pipe lengths to receive water from the mains supply, have it delivered to the collectors and then to the outlet points. This raises the cost of the system, and sometimes affects the aesthetics of the building. In addition, there exist technical problems such as low efficiency, high heat loss, and poor solar energy harvesting capability. The key to guaranteeing an efficient operation of the system and achieving maximum benefits to users' lies in how well it is designed [3]. Every location on earth receives sunlight at least part of the year. The amount of solar radiation that reaches any one "spot" on the earth's Surface varies according to geographic location, time of the day, season, local landscape and local weather. The shape of the earth makes the sun to strike its surface at different angles ranging from $0^{\circ}$ (just above the horizon) to $90^{\circ}$ (directly overhead) [4]. The average rate of solar energy (or solar flux) as described by Wallace [5], arriving at the stratosphere before suffering any losses is $1.37 \mathrm{~kW} / \mathrm{m}^{2}$ (the solar constant). The surface area of the earth over which this flux is averaged over time is $4 \pi r^{2}$. After averaging the sun oriented steady, and subtracting the scattered and consumed motion by the climate and mists, the last motion striking the world's surface is $174.7 \mathrm{~W} / \mathrm{m}^{2}$.

*Corresponding author: seretseom@mopipi.ub.bw 


\section{Literature Review-}

Solar water heating systems depend on; the type of solar collector used, the weather conditions, the hot water demand and the temperature of the water heated can vary from tepid to nearly boiling[6]. Most solar systems are meant to furnish 20 to $85 \%$ of the annual demand for hot water, the remainder being met by conventional heating sources, which either raise the temperature of the water further or provide hot water when the solar water heating system cannot meet demand (e.g. at night)[6]. Solar hot water systems can be used wherever moderately hot water is required. Solar water heating technology has been embraced by a number of developing countries with both strong solar resources and costly or unreliable conventional energy supplies[6]. The dynamic frameworks are more unpredictable and costly and for the most part have higher efficiencies, their qualities being $35 \%-80 \%$ higher than those of the inactive frameworks. Dynamic sun powered water radiators depend on electric pumps, valves, and controllers to flow water, or other warmth exchange liquids (as a rule a propylene-glycol blend) through the authorities [3]. Passive direct systems are also used in warmer climates.

The special normal for these frameworks is that they don't utilize pumps or other electrical segments, in this way giving a straightforward and solid framework. In an audit of SHWS for residential and industrial applications did by [7] and [8] SHWS were gathered into two general classifications (passive and active), each of them working in either direct or indirect mode. They reported their performances, uses and applications, and factors considered for their selection. The most well-known detached frameworks are the thermosyphon and fundamental authority stockpiling frameworks. Roundabout thermosyphon frameworks could likewise be utilized as a part of colder atmospheres [3]. Integral-collector capacity frameworks comprise of at least one stockpiling tanks set in a protected box with a coated side confronting the sun. The thermosyphon framework utilizes a level plate gatherer and a different stockpiling tank that must be found higher than the collector. The collector is similar to those used in active systems.

The first published analysis of thermosyphon solar water heater trail was by[8]. There have been numerous different distributions on the examination of these frameworks yet they are altogether in light of the first definition. For checking the hypothetical outcomes, he tried two thermosyphon frameworks with various qualities and the outcomes adjusted well to those anticipated [9], did the investigation of the warm execution of the thermosyphon water radiator unit to demonstrate its relevance in Bahrain. Their results show that the system is quite suitable for application in Bahrain weather conditions. [10] Made some fabrications and experimented on a single-phase open thermosyphon to utilize solar energy for water heating. Their exploratory work was finished utilizing protected water tank and protected associating funnel between the tank and the level plate authority. From their gathered information, execution parameters, for example, momentary gatherer.

\section{Scenario in Botswana: Problem Statement-}

Through observation and documented records, it was found out that most of the commercial and industrial hot water demands in Botswana are met mainly by the use of electric heaters. The issues related with the utilization of these electric warmers are: the rising vitality cost, ecological concerns, and the draining idea of the present essential vitality sources. These issues can be taken care of by removing a portion of the vitality interest for boiling water purposes from power in areas where the high temp water is promptly required, for example, in healing centers, inns and schools by utilizing sunlight based water warming frameworks.

On that point, the investigators proposed to design a thermosyphon SHWS for 8- person bed and breakfast to try to curl the problem of using electric heaters, as it will mean reduced load on the nation power grid. Other inline objectives are researching and designing (using software and mathematical models) a suitable solar thermal hot water heating system for eight person bed and breakfast. Identifying a solution for heating water to solve the power supply crisis for eight person bed and breakfast in Botswana by constructing a typical flat plate solar collector for the designed solar water heating system using ASTM standard and testing the fabricated flat plate collector for performance and efficiency.

\section{Methodology}

The territories of intrigue incorporates the comprehension of the different kinds of sun based gatherers normally utilized, sun powered boiling water estimating and utilization propensities particularly in motels and visitor houses or overnight boardinghouse places, standards of financial assessment while taking buy choices of sun powered water radiators, computation of yearly vitality and cost funds and in addition the payback time of sunlight based water warmers. The method for sizing a solar thermal system for 8 person bed and breakfast is on peak hot water demand with additional capacity to provide potential for future expansion and safety margins. Sizing a solar water heating system is by determining the collector area that will meet the heating load, depending upon the insolation level and in some cases, the collector area that will give maximum life cycle solar savings (minimize life cycle cost) of SWH system[3].

SWH framework estimating likewise includes the assurance of the required stockpiling tank ability to give a vitality

*Corresponding author: seretseom@mopipi.ub.bw 
support between times of low insolation levels, for example, 30 night and overcast days, and times of high insolation levels. Different segments, for example, the sensors and mechanical help structures can be chosen as long as they are not out of extent since they are heartless to the warm execution of the SWH framework. According to the National Energy Renewable Laboratory (NREL) of the US Department of Energy, a workshop on solar thermal technology and applications by Roger Taylor in June 2006 provided the following values for hot water usage in various types of buildings [11].

Various mathematical models were investigated, and the following method below by [12] was adopted for the studies. This model was adopted for this study because it goes beyond the energy balance equations and adds heat transfer equations of collector's components. Hypothetical conditions will be utilized for assessing the warm effectiveness of the authority, outlet water temperature and different warmth misfortunes from the framework. The manufacturing simplicity and absence of moving parts make it an interesting technological solution for production of hot water in eight person bed and breakfast.

\section{Useful Heat Output of a non- concentrating Solar Collector}

If the rate of solar energy arriving on the collector surface $\operatorname{area}(A), \mathrm{m}^{2}$, perpendicular to the line of the sun is $I$ the solar radiation, in $\mathrm{W} / \mathrm{m}^{2}$, then the amount of solar energy being received by the collector is:

$Q_{i}=I \cdot A$

However, parts of this radiation are reflected back to the sky, absorbed by the glazing and the rest is transmitted through the glazing, reaching the absorbed plate as short wave radiation. Incorporating the rates of transmissions of the cover and the absorption rate of the absorber,

$Q_{i}=I \cdot \tau \cdot \alpha \cdot A$

As the collector absorbs heat, its temperature becomes higher than its surroundings and a temperature gradient is created. This causes loss of heat to the atmosphere through convection and radiation. The heat loss rate $Q_{o}$ is dependent on the collector overall heat transfer coefficient $U_{L}$, and the temperature difference between the collector $t_{c}$ and ambience $t_{a}$.

$Q_{o}=U_{L} \cdot A\left(t_{c}-t_{a}\right)$

$U_{L}=\frac{1}{\frac{1}{h_{n}}+\frac{L_{n}}{k_{n}}}$
Thus, the rate of useful energy extracted by the collector $Q_{u}$, expressed as a rate of heat extraction under steady state conditions-

$$
\begin{array}{r}
Q_{u}=Q_{i}-Q_{o}=I \cdot \tau \cdot \alpha \cdot A-U_{L} \cdot A\left(t_{c}-t_{a}\right) \\
=A\left[I \cdot \tau \cdot \alpha-U_{L}\left(t_{c}-t_{a}\right)\right]
\end{array}
$$

The useful energy extraction rate may also be expressed as the amount of heat carried away in the HTF passed through it:

$Q_{u}=\dot{m} \cdot c_{p}\left(t_{o}-t_{i}\right)$

Where, $\dot{m}$ is the mass flow rate, $c_{p}$ is the specific heat, and $t_{o} \& t_{i}$ are the outlet and inlet temperatures of the HTF, respectively. A collector heat removal factor $F_{R}$ is employed as this quantity. The $F_{R}$ is the ratio of heat delivered to the HTF and heat in the condition that the overall collector plate temperature equals the inlet fluid temperature.

$F_{R}=\frac{\dot{m} \cdot c_{p}\left(t_{o}-t_{i}\right)}{A\left[I \cdot \tau \cdot \alpha-U_{L}\left(t_{i}-t_{a}\right)\right]}$

Introducing the collector heat removal factor to Eqn. 7 forms the widely used relationship for measuring collector energy gain known as the "Hottel-Whillier-Bliss equation."

$Q_{u}=F_{R} \cdot A\left[I \cdot \tau \cdot \alpha-U_{L}\left(t_{i}-t_{a}\right)\right]$

The performance of a solar collector could be measured using the collector efficiency $\eta$.

$$
\begin{aligned}
\boldsymbol{\eta}=\frac{Q_{u}}{A I}=\frac{F_{R} \cdot A\left[I \cdot \tau \cdot \alpha-U_{L}\left(t_{i}-t_{a}\right)\right]}{A I} \\
=\boldsymbol{F}_{\boldsymbol{R}}\left[\boldsymbol{\tau} \cdot \boldsymbol{\alpha}(\mathrm{t}) \boldsymbol{U}_{\boldsymbol{L}}\left(\frac{\boldsymbol{t}_{\boldsymbol{i}}-\boldsymbol{t}_{\boldsymbol{a}}}{\boldsymbol{I}}\right)\right]
\end{aligned}
$$

\section{Characteristics \& simulation programming}

We led an examination that included sun oriented accessibility, water use and vitality utilization information gathering and investigation. Online solar calculators were used to aid the experiment carried out on solar radiation to be used to determine the tilt angle. The warm execution and monetary investigation of the solar water heating system was carried out in this research using the $T^{*}$ SOL $®$ programming software. The programme uses the online methodology employed to compute total global annual irradiation for the climate location, fraction of diffuse component of total global annual irradiation, mean outside temperature, the collector surface area irradiation, required size of collector area, thermal performance of the system in terms of the energy produced by the collectors and collector loop, installed collector power, $\mathrm{CO} 2$ emissions avoided, solar fraction, electricity savings and system efficiency.

* Corresponding author: seretseom@mopipi.ub.bw 
The programme then performs the economic analysis of the system in terms of life cycle savings, total running cost, net present value, payback period and the cost of solar energy. In order to gather information on solar irradiance an instrument used to measure solar irradiance named pyranometer, is used to verify data obtained from department of metrological services and position the flat plate collector. $T * S O L \circledR$ software program which is an entire reproduction program that enables an expert to measure and recreate sun powered warm frameworks of various classes, for example, household boiling water, process warming, air authorities, space-warming, swimming pool, and support tank frameworks would be utilized to estimate the proposed sunlight based water warming framework for the clinic. Other than mimicking, the warm and monetary examination and reports would be created for the proposed sun powered water warming framework using $\mathrm{T}^{*} \mathrm{SOL} \AA$.

\section{Design and analysis}

Solar irradiation data was collected by performing an experiment at University of Botswana, explore on contemporary sunlight based water warming innovations, and a monetary examination to plan a fitting sun powered water warming framework. Keeping in mind the end goal to get the most vitality from the sun oriented boards, it was necessary to let the panels face to the solar radiation directly for most of the time as recommended by Close[8]

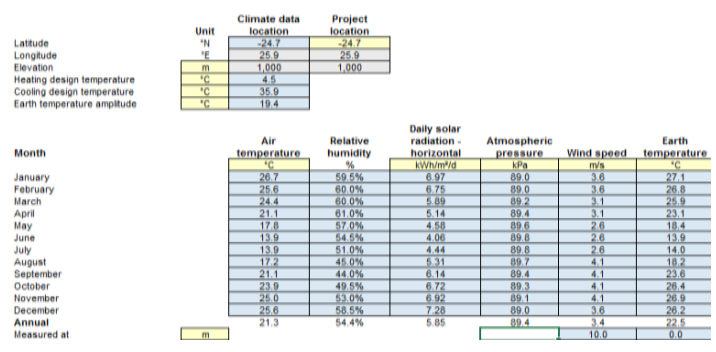

Fig. 1: Monthly average daily global solar irradiation data for Gaborone Source: RET Screen International climate data for Gaborone, 2012.[13]

Figure 1 shows the monthly average daily global solar irradiation data for Gaborone .To calculate these design parameters and evaluate the sensitivity and effect of some design parameters on the performance of thermosyphon solar water heating (TSWH) system, the design method from [14] was adopted.
Table 1: Hot water demand for different users at a hot temperature of $50^{\circ} \mathrm{C}$

\begin{tabular}{|l|l|l|l|l|}
\hline & & $\begin{array}{l}\text { Low } \\
\text { demand } \\
\text { (litres) }\end{array}$ & $\begin{array}{l}\text { Medium } \\
\text { demand } \\
\text { (litres) }\end{array}$ & $\begin{array}{l}\text { High } \\
\text { demand } \\
\text { (litres) }\end{array}$ \\
\hline $\begin{array}{l}\text { Residential } \\
\text { buildings }\end{array}$ & $\begin{array}{l}\text { per person } \\
\text { and day }\end{array}$ & 30 & 50 & 60 \\
\hline Sport facilities & $\begin{array}{l}\text { per } \\
\text { shower }\end{array}$ & 20 & 30 & 50 \\
\hline Accommodation & per bed & 20 & 40 & 60 \\
\hline
\end{tabular}

\begin{tabular}{|l|l|}
\hline 10 rooms ( 8 beds) $\mathrm{B}=8$ & $\begin{array}{l}\text { Hot water demand per person (DHW): } \\
\text { Medium demand }\end{array}$ \\
\hline $\begin{array}{l}\text { Assuming } 100 \% \text { occupancy } \\
(\mathrm{O})=8 \text { people }\end{array}$ & $\begin{array}{l}\text { Hot water demand kitchen: } 160 \\
\text { litres/day(HWDK) }\end{array}$ \\
\hline
\end{tabular}

\begin{tabular}{|l|l|l|}
\hline Cold water: $22^{\circ} \mathrm{C}$ & $\begin{array}{l}\text { Hot water (storage): } \\
55^{\circ} \mathrm{C}\end{array}$ & $\begin{array}{l}\text { Hot water at shower: } \\
50^{\circ} \mathrm{C}\end{array}$ \\
\hline
\end{tabular}

*Average solar radiation: May to July (For high solar fractions: $75-80 \%)$

The solar heating system is expected to heat up the cold water from mains supply line (from the water utilities cooperation) at $22^{\circ} \mathrm{C}$ to $55^{\circ} \mathrm{C}$. When dealing with the calculation aspect, the energy demand can be thought as the equal value of heating the cold supply water from the water supply company from $22^{\circ} \mathrm{C}$ to $35^{\circ} \mathrm{C}$ in the ideal situation (neglect the energy losses in the system).

$Q=c m \Delta T$ Where: $c=4200 \mathrm{~J} / \mathrm{kg} \cdot{ }^{\circ} \mathrm{C} ; \quad m=\rho V$;

$V=0.6 \mathrm{~m}^{3}$ per day; $\quad \rho=1000 \mathrm{~kg} / \mathrm{m}^{3} ; \Delta T=55^{\circ} \mathrm{C}-$

$22^{\circ} \mathrm{C}=33^{\circ} \mathrm{C}$

Therefore $Q=4200 \times 0.6 \times 1000 \times 33=83160000 \mathrm{~J}=$ $23.1 \mathrm{kWh}($ per day $) \approx 23 \mathrm{kWh}$ (per day)

From the table it can be seen that the collector and the storage tank were sized properly as it can be seen from the table above. The calculated values correspond to the values in the table.

Table 2: Dimensioning of domestic hot water solar systems for southern African Conditions

\begin{tabular}{|l|l|l|l|}
\hline $\begin{array}{l}\text { Daily } \\
\text { water } \\
\text { demand } \\
{[\text { litres] }}\end{array}$ & $\begin{array}{l}\text { Solar storage } \\
\text { capacity } \\
\text { [litres] }\end{array}$ & $\begin{array}{l}\text { Solar storage } \\
\text { capacity [litres] } \\
\text { Collector area* } \\
\text { SV [m2] }\end{array}$ & $\begin{array}{l}\text { Collector area* } \\
\text { SC } \\
{\left[\mathbf{m}^{2}\right]}\end{array}$ \\
\hline 50 & $50-75$ & $1.0-1.5$ & $0.9-1.3$ \\
\hline 100 & $100-150$ & $2.0-3.0$ & $1.5-2.5$ \\
\hline 200 & $200-300$ & $3.5-4.5$ & $3.0-4.0$ \\
\hline 300 & $300-450$ & $4.5-6.0$ & $4.0-5.0$ \\
\hline 500 & $500-750$ & $7.5-10$ & $6.0-8.5$ \\
\hline 1000 & $1000-1200$ & $14-20$ & $11-16$ \\
\hline 2000 & $2000-2500$ & $30-40$ & $24-32$ \\
\hline 4000 & $4000-5000$ & $60-80$ & $50-70$ \\
\hline 10000 & $10000-12000$ & $140-200$ & $110-160$ \\
\hline
\end{tabular}

*) depending on the required solar fraction (SV ... coating of solar varnish) (SC-selective coating) Source: [14] 


\section{Energy Calculations}

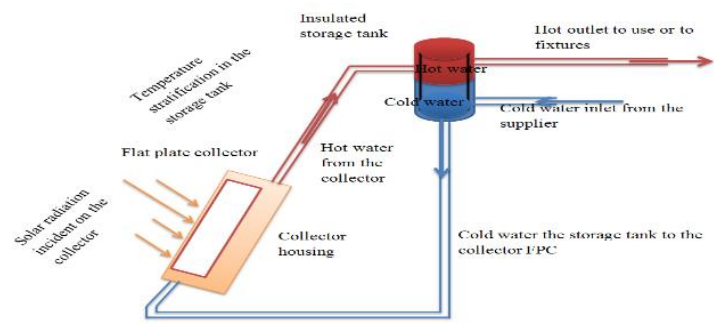

Fig. 2: Schematic of a flat plate solar water heating system

As per the figure 2 process, the water enters the solar flat panel at an average supply temperature $T_{i}=27^{\circ} \mathrm{C}$. It is desired that after one pass through the collector, the water will exit at $T_{o}=32^{\circ} \mathrm{C}$. Calculating for the mass flow rate of the fluid in the solar panel required to achieve this, the useful energy gained, and the efficiency of the collector. The amount of solar radiation in Botswana received by the flat-plate collector-

$$
Q_{i}=I_{C} A=469.9 \times(1.75 \times 1.17)=0.96212025 \mathrm{~kW}
$$

The actual heat input into the flat-plate panel $-Q_{i, a c t}=$ $\tau \alpha Q_{i}=0.84 \times 0.97 \times 0.96212025=0.783935579 \mathrm{~kW}$ and, the heat lost by the collector to the surroundings: $Q_{o}=U_{c} A\left(T_{c}-T_{a}\right)$

$$
\begin{aligned}
& =6.844616513 \\
& \times(1.75 \times 1.17)(50-30) \\
& =0.2802870462 \mathrm{~kW}
\end{aligned}
$$

Using energy balance and assuming that $F_{R}=1$ : $\dot{m} C_{P}\left(T_{o}-T_{i}\right)=Q_{i}-Q_{o}$

$$
\begin{aligned}
& \dot{m}=\frac{Q_{i}-Q_{o}}{C_{P}\left(T_{o}-T_{i}\right)}=\frac{0.96212025-0.2802870462}{4.188(32-28)} \\
& =0.0407016 \mathrm{~kg} / \mathrm{s} \\
& =2.442096003 \mathrm{l} / \mathrm{min}
\end{aligned}
$$

Therefore, in order to raise the temperature of water by $4{ }^{\circ} \mathrm{C}$ after every cycle, the HTF will have to flow 2.442096003l/min.

- The useful energy gained per second from the flatplate collector:

$$
\begin{gathered}
Q_{u}=\dot{m} C_{P}\left(T_{o}-T_{i}\right)=0.0407016 \times 4.188 \times 4 \\
=\mathbf{0} \mathbf{0 . 6 8 1 8 3 3 2 0 3} \mathbf{k W}
\end{gathered}
$$

- The efficiency of the collector $\eta=\frac{Q_{u}}{A I}=$ $\frac{\mathbf{0 . 6 8 1 8 3 3 2 0 3}}{0.96212025}=70.86777388 \%$

Solar water heating system for 8 person bed \& breakfast has been analyzed using $T^{*}$ SOL ${ }^{\circledR}$ software programme by providing technical and economic input parameters described on table6. The detail procedure for the analysis is provided in appendix B. The flat plate collector (type kf) is

\begin{tabular}{|c|c|c|}
\hline \multirow[t]{2}{*}{ Performance parameters } & \multicolumn{2}{|l|}{ Type of collector } \\
\hline & $\begin{array}{l}\text { Flat plate } \\
\text { collector }(\mathrm{kf})\end{array}$ & $\begin{array}{l}\text { Flat plate } \\
\text { collector } \\
\text { (standard) }\end{array}$ \\
\hline Gross Area (Ag) & $8.2 m^{2}$ & $8.2 m^{2}$ \\
\hline Aperture(active)Area(Ap) & $2.05 m^{2}$ & $2.05 m^{2}$ \\
\hline 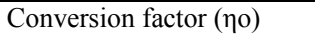 & $79.9 \%$ & $78 \%$ \\
\hline $\begin{array}{l}\text { Linear heat loss coefficient } \\
\text { (a1) }\end{array}$ & $3.80\left(W / m^{2} . \mathrm{K}\right)$ & $3.8\left(W / m^{2} K\right)$ \\
\hline $\begin{array}{l}\text { Quadratic heat loss } \\
\text { coefficient (a2) }\end{array}$ & $0.018\left(\frac{W}{m^{2} K^{2}}\right)$ & $0.03\left(W / m^{2} K^{2}\right)$ \\
\hline $\begin{array}{l}\text { Collector fluid water } \\
\text { Specific heat capacity }(\mathrm{Cp})\end{array}$ & $4200 \mathrm{~J} / \mathrm{kg}-{ }^{\circ} \mathrm{C}$ & $4200 \mathrm{~J} / \mathrm{kg}-{ }^{\circ} \mathrm{C}$ \\
\hline $\begin{array}{l}\text { Nominal flow rate per } \\
\text { collector }\end{array}$ & $0.030 \mathrm{~kg} / \mathrm{s}$ & $0.05 \mathrm{~kg} / \mathrm{s}$ \\
\hline
\end{tabular}
supplied by Solahart industries Pty Ltd and the other one supplied by Standard (type standard flat plate collector) were analyzed.

\footnotetext{
Corresponding author: seretseom@mopipi.ub.bw
}

The collector performance parameters and their technical specifications are given in the Table 3 below.

Table 3: Collector performance parameters and technical specifications

*Source: $\mathrm{T} * \mathrm{SOL} \AA$ software programme catalogue data.

\section{Results and Discussions}

From the two graphs obtained from experimental results, it can be seen that from graph 1 as the incident radiation experiences progressive increase there is a corresponding increase in the useful energy gained by the black body shown in graph 2 by rise in temperature. In relation to our project, this energy will be responsible for driving by convection buoyancy the system fluid flow, depending on the thermal properties of water.

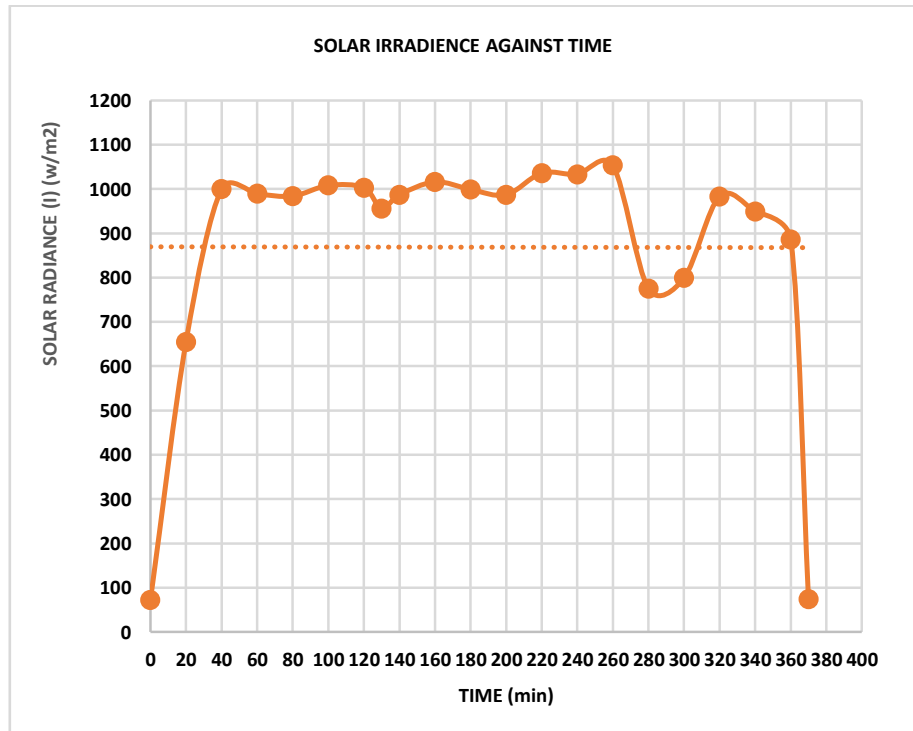

Fig.3: solar irradiance against time 


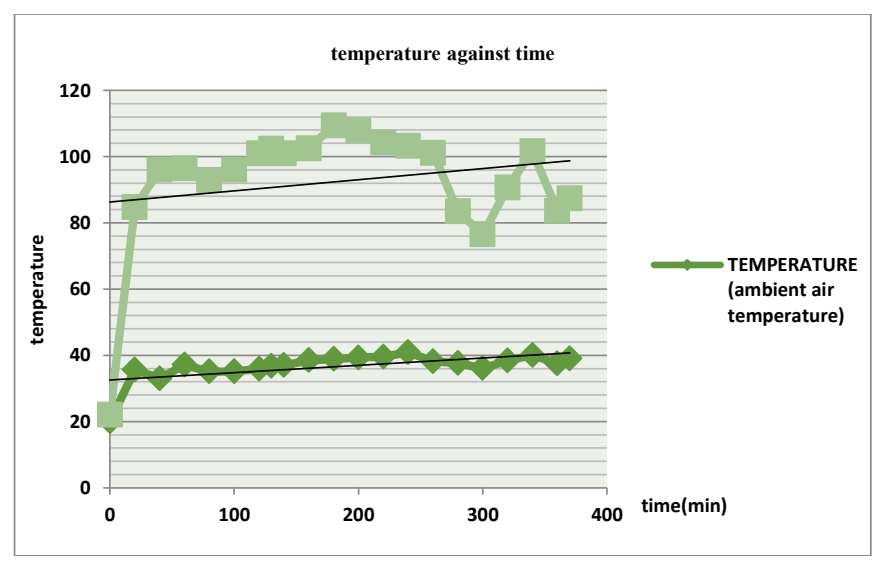

Fig.4. Temperature against time

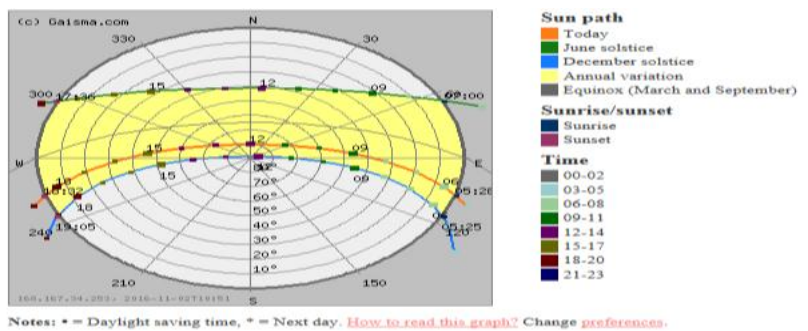

Fig. 5. Gaborone, Botswana-Sun Path Diagram

Source: http://www.gaisma.com/en/location/gaborone.html

It can be seen from figure 5 that the sun rises from the South-East (azimuth $=105^{\circ}$ ) in Gaborone at 05:28. Sunset happens at 18:32 when the sun is in the South-West (azimuth $=255^{\circ}$ ). On that day the elevation angle is approximately 80 degrees at noon. The insolation increases from 7.00 CAT until it reaches its maximum value (1000, $894,640,430 \mathrm{~W} / \mathrm{m} 2$ ) at $12.00 \mathrm{CAT}$ for the day of the experiment, summer, autumn/spring and winter seasons, then it begins to decrease. The useful energy follows the same pattern on figure 4 and auxiliary heat would be needed on winter and part of autumn/spring seasons' days. A solar-collection approach was to alter the solar collector at different tilt angles and azimuth rotation angle for the full duration of its lifetime. The geographic coordinates of Gaborone on [15] are: Latitude: $-24.62821^{\circ}$, Longitude: $+25.923147100^{\circ}$, Altitude: $1014 \mathrm{~m}$.

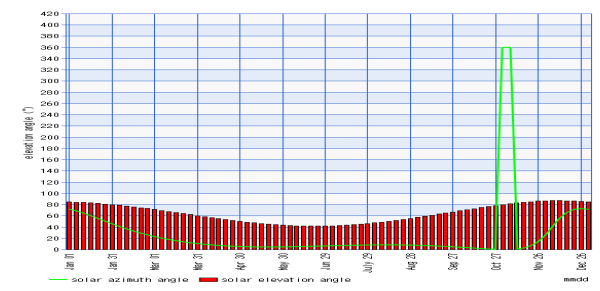

Fig. 6: Solar azimuth and elevation angle

Figure 6 shows the Gaborone solar azimuth and elevation angle for the whole year 2016, [15]

* Corresponding author: seretseom@mopipi.ub.bw
Therefore from the graph the mean solar elevation angle of 2016 Gaborone is $64.52^{\circ} \approx 65^{\circ}$ and the mean solar azimuth is $28.03^{\circ} \approx 28^{\circ}$. The solar panel will face true north because the installation site will be in Botswana which is in the southern hemisphere.

\section{SWH Simulation Results}

The detail procedure for the analysis is provided in appendix A. The figure beneath demonstrates the rundowns of the yearly execution of the sun based water warming framework in light of the two proposed sunlight based gatherers from the $\mathrm{T}^{*} \mathrm{SOL} \AA$ software programme in terms of the collector array and thermal performance. Therefore, from the summaries of the results in figure below, any of the two collectors can be used.

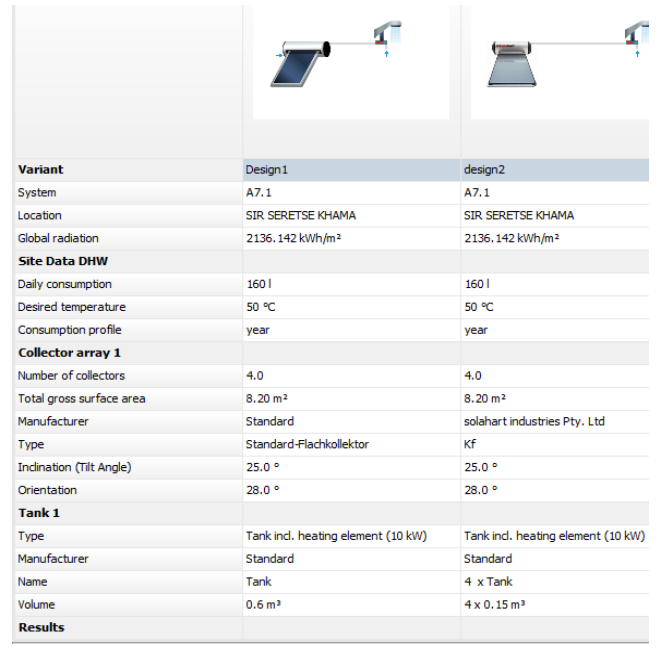

(a)

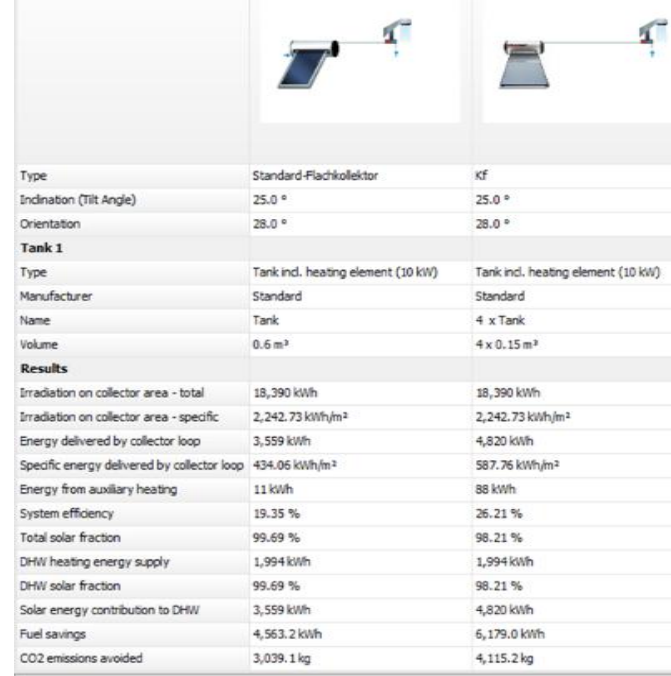

(b)

Fig. 7. (a \& b) Summary of the SWH System Annual Performance 


\section{Thermal performance analysis}

The thermal performance of the SWH system based on the two collector types is given in terms of the fuel savings, solar fraction, solar contribution to domestic hot water heating load (E- Solar-DHW), energy required for auxiliary heating (E- Aux) and $\mathrm{CO} 2$ emissions avoided and system efficiency as shown in figure below.

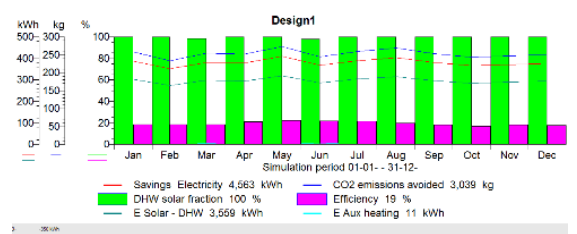

Fig. 8. Thermal performance analysis for standard-flachkollector

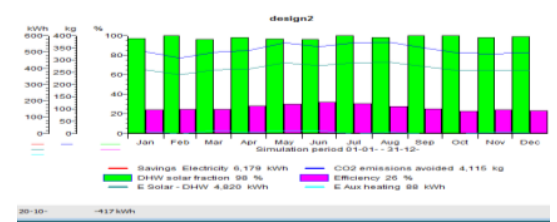

Fig. 9. Thermal performance analysis for $\mathrm{kf}$ collector

In terms of the annual collector performance analysis, the $\mathrm{kf}$ collector has lower solar fraction but shows increase of value in terms of fuel cost savings (saving electricity), solar contribution to annual heating load and the amount of $\mathrm{CO} 2$ emissions avoided more than that of the standardflachkollektor as shown in Figures 8 and 9respectively.

\section{Financial analysis}

The figure 10 shows an annual loan instalment of BWP 5000 (taking if US\$1=BWP1) payable to the financial institution that granted the loan for a period of 5 years. The life cycle cost of the system (comprising an initial investment and total operating cost) amounts to BWP 10000 given a positive net present value of BWP 47,040 indicating the economic viability of the solar water heating system as proposed for the 8 person bed and breakfast. The proposed system, also from the economic analysis, has a payback period of 0.7 years.

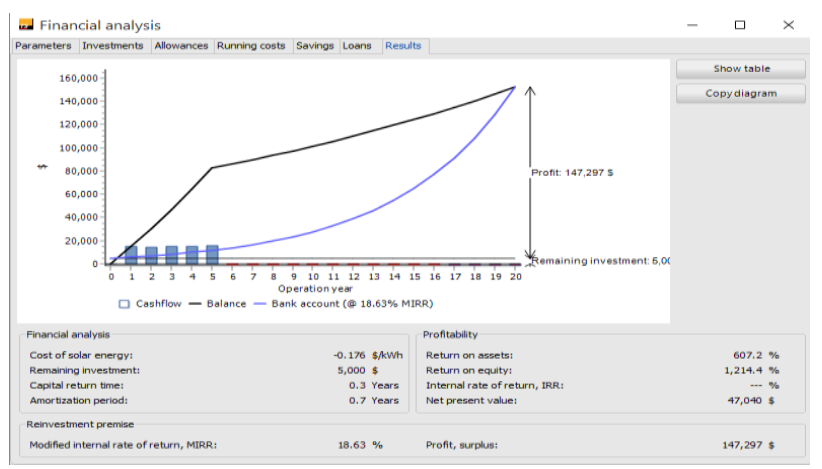

Fig. 10. Results of Financial analysis, If US\$1=BWP1

\section{Energy analysis of solar water heater}

Ambient air Temperature at the start of the experiment $=19.6^{\circ}$; Inlet temperature $T_{0}$ is assumed to be the same throughout the whole experiment $=25^{\circ}$; Pressure of the system $=4$ bars and the Flow rate was measured to be $0.013 \mathrm{~kg} / \mathrm{s}$. In table 4 below it should be noted that the results were recorded instantaneously when the water from the valve was opened immediately. The water was supplied directly from the water mains/stand pipe. The temperatures were measured in 30 minutes interval from $1035 \mathrm{hrs}$ to $1605 \mathrm{hrs}$. The inlet temperatures were higher than the theoretical ones because the temperatures were measured instantaneously after a period of 30 minutes, from there the valve of the stand pipe was closed until the next reading was collected. Because of this the collector had enough time to overheat on its own without receiving water.

Table 4: Time taken for experiment and inlet and outlet temperatures recorded

\begin{tabular}{|l|l|l|l|}
\hline Time & $\begin{array}{l}\text { Inlet } \\
\text { temp. }\left(t_{i}\right)\end{array}$ & $\begin{array}{l}\text { Outlet } \\
\text { temp. }\left(t_{o}\right)\end{array}$ & $\begin{array}{l}\text { Temp. gain } \\
(\Delta T)=\left(\left(t_{o}\right)-\left(t_{i}\right)\right)\end{array}$ \\
\hline 1035 & 25 & 40 & 15 \\
\hline 1105 & 25 & 45 & 20 \\
\hline 1135 & 25 & 63 & 38 \\
\hline 1205 & 25 & 66.7 & 41.7 \\
\hline 1235 & 25 & 85 & 60 \\
\hline 1305 & 25 & 87.3 & 62.3 \\
\hline 1335 & 25 & 76.4 & 51.4 \\
\hline 1405 & 25 & 75 & 50 \\
\hline 1435 & 25 & 50.2 & 25.2 \\
\hline 1505 & 25 & 68.9 & 43.9 \\
\hline 1535 & 25 & 59.1 & 34.1 \\
\hline 1605 & 25 & 55 & 30 \\
\hline Avg temp & 25 & 64.3 & 39.3 \\
\hline & & & \\
\hline
\end{tabular}


The highest outlet temperature of $87.3^{\circ} \mathrm{C}$ was recorded at $1305 \mathrm{hrs}$, this is the point at which the sun is directly in line with the collector. A large temperature drop was observed at $1435 \mathrm{hrs}$, this was because of the cloud clover which was experienced around that time. The lowest temperature outlet was $40^{\circ} \mathrm{C}$ which were experienced at the beginning of the experiment.

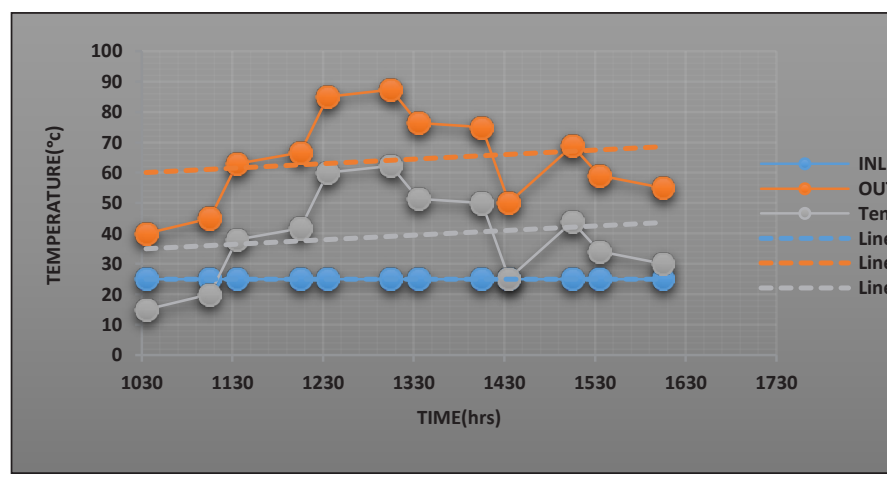

Fig.11. Time against Temperatures of the collector inlet and outlet

From figure 11 it can be seen that the temperatures were gradually increasing until at $1305 \mathrm{hrs}$ where the graph was at its pick point. From there the graph gradually decreases until at the end of the experiment. An unusual decrement was experienced at $1435 \mathrm{hrs}$ due to the above explained reason of cloud cover. The figure 12 below shows the relationship between time of the day versus Useful Energy Extraction Rate $\left(Q_{u}\right)$ and Collector Efficiency $(\eta)(\%)$.Flow rate was measured to be $=\mathbf{0 . 0 7 7} \mathbf{~} \mathbf{g} / \mathrm{s}$

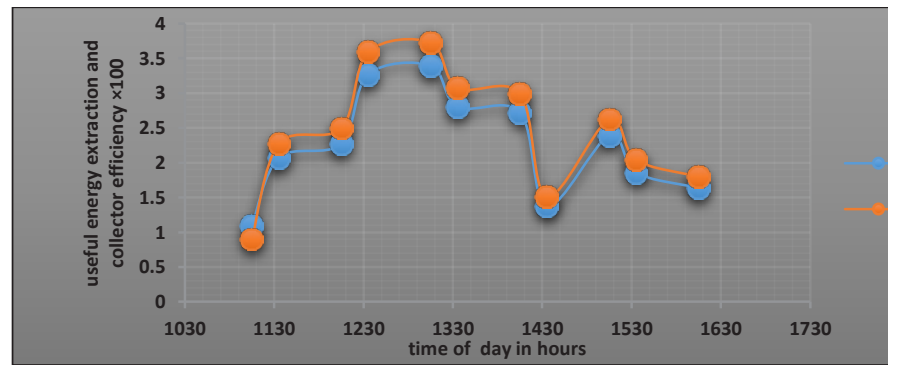

Fig. 12. Solar water heater experiment 2 results and analysis

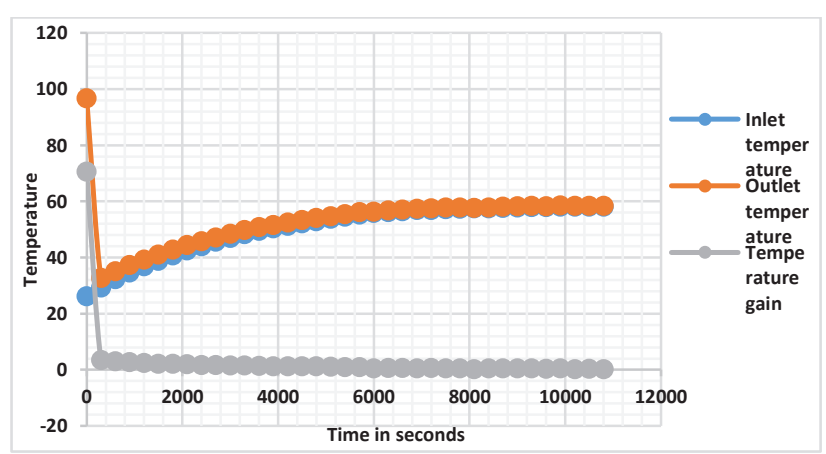

Fig.13. Relationship of temperature inlet, outlet and gain plotted against time

* Corresponding author: seretseom@mopipi.ub.bw
From figure 13 above it can be seen that the inlet and outlet temperatures were showing a direct relationship as compared to the temperature gain. Thereby, decreasing the heat absorbed by the collector. This is further shown by the graph which was plotted by the data harvester itself.

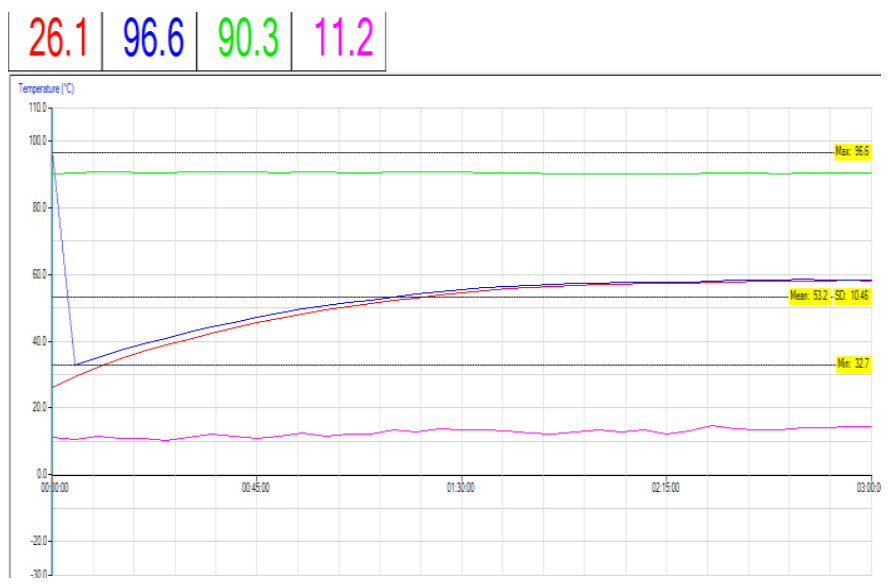

Fig. 14. Relationship of time of the day with mean temperature difference

The figure 14 above shows the relationship of time of the day with mean temperature difference by the circulating fluid red, the graph follows a trend of direct proportionality.

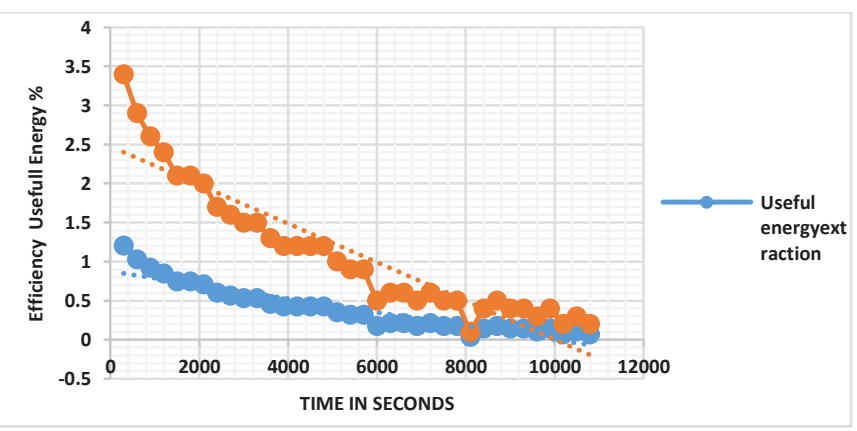

Fig. 15. The Efficiency Graph

Figure 15 above show the relationship of efficiency with heat absorbed by the circulating fluid. For consistent episode vitality, the proficiency of the level plate authority relies upon the warmth consumed by the circling water. The warmth consumed by the gatherer relies upon such a large number of elements, for example, air mass factor. Figure 16 below shows the schematic of proposed model.

$$
\begin{aligned}
\text { Energy saved } & =Q_{u}-W_{\text {pump }}=0.3905-0.37 \\
& =0.0488 \mathrm{~kW}=\mathbf{2 0 . 5} \mathbf{W}
\end{aligned}
$$




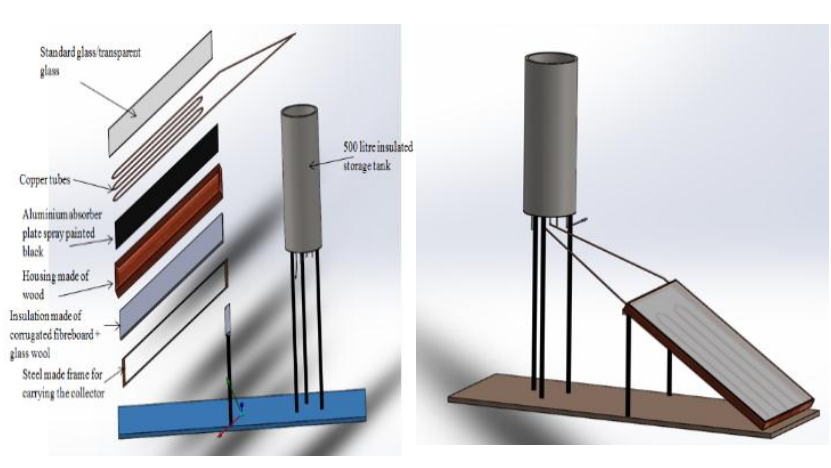

Fig. 16. Schematic of proposed model

\section{Conclusion}

The research was analyzed using theoretical and mathematical analysis and the $T^{*} \mathrm{SOL} \otimes$ simulation programme for solar thermal heating systems. The metrological solar data of Gaborone was processed using software's such as RET-Screen to obtain the monthly average daily solar radiation of Gaborone for recommended average day of the months. The month of April with the worst amount of the average daily solar radiation was considered as the design month and solar radiation and weather data of this month was used as input data for system design and parametric studies. System efficiency was $19.8 \%$ using $\mathrm{T}$-Sol and of the mathematical modeling was $70 \%$.

The average efficiency of mathematically designed system was higher than the designed value efficiency. The economic performance of the system has proved that the proposed solar water heating system is feasible because it gives a positive net present value of BWP 47,040 with a payback period of 0.7 years. However, bank negotiations to reduce the interest rate to 8 percent or less would ensure a payback period of 5 months or less. Since the prices of solar water heating system components are dynamic, using the cost of the system from T-sol item database and making presumptions concerning increment in vitality and running expense may digress from the genuine financial situations of the investigation that has been done in this examination. In conclusion, at a steady radiation, the higher the heat absorbed, the higher the efficiency of the collector.

The use of the flat plate solar collector for domestic and commercial heating (for eight person bread and breakfast) purposes in Gaborone, Botswana is feasible since reasonable temperatures (outlet from the collector, $\left(t_{o}\right)$ were realized.

\section{Reference}

1. AEE - Institute for Sustainable Technologies, "Dimensioning and Design of Solar Thermal Systems."

2. IEA, World Energy Outlook 2014. (2014).

3. J. a. Duffie, W. a. Beckman, and W. M. Worek, Solar Engineering of Thermal Processes, 4nd ed., vol. 116. (2003).

4. K. Chuawittayawuth and S. Kumar, "Experimental investigation of temperature and flow distribution in a thermosyphon solar water heating system," Renew. Energy, vol. 26, no. 3, pp. 431-448, (2002).

5. P. V. H. John M.Wallace, Atmospheric Science: An Introductory Survey, no. November. Canada: Elsevier Inc., (1999).

6. H. Garg, Solar Water Heating Systems. Springer Science \& Business Media., (2012).

7. M. P. Malkin, S. A. Klein, J. A. Duffie, and A. B. Copsey, "A Design Method for Thermosyphon Solar Domestic Hot Water Systems," J. Sol. Energy Eng., vol. 109, no. 2, pp. 150-155, May (1987).

8. D. J. Close, "The performance of solar water heaters with natural circulation," Sol. Energy, vol. 6, no. 1, pp. 33-40, (1962).

9. A. A. Karaghouli and W. E. Alnaser, "Experimental study on thermosyphon solar water heater in Bahrain," Renew. Energy, vol. 24, no. 3-4, pp. 389-396, (2001).

10. S. Sadhishkumar and T. Balusamy, "Performance improvement in solar water heating systems - A review," Renew. Sustain. Energy Rev., vol. 37, pp. 191198, 2014.

11. T. Roger, "Solar thermal technology and applications," 2006, p. 7.

12. G. N. Tiwari, A. Tiwari, and Shyam, Handbook of Solar Energy. 2016.

13. RETscreen, "Retscreen international climate data for gaborone, 2012." [Online]. Available: https://eosweb.larc.nasa.gov/sse/RETScreen/.

14. W. Weiss, "SOUTHERN AFRICAN SOLAR THERMAL TRAINING AND DEMONSTRATION INITIATIVE," AEE - Institute for Sustainable Technologies, 2009.

15. Keisan, "KEISAN ONLINE CALCULATOR," 2016. [Online]. Available: http://keisan.casio.com. [Accessed: 21-Sep-2016]. 